\title{
Selenium concentrations and glutathione peroxidase activities in whole blood of New Zealand residents
}

\author{
BY CHRISTINE D. THOMSON, HEATHER M. REA, \\ VERONICA M. DOESBURG AND MARION F. ROBINSON \\ Department of Nutrition, University of Otago, \\ Dunedin, New Zealand \\ (Received 5 fanuary 1977 - Accepted 21 fanuary 1977)
}

\begin{abstract}
I. A relationship was found between selenium concentrations and glutathione peroxidase ( $E C$ I. I I. . . . 9) activities in whole blood of 264 New Zealand residents $(r 0.71, P<0.001$ ). 2. New Zealand residents returning from visits overseas of 7 months to 3 years had elevated blood Se, but normal GSH-Px activities, whereas for some new settlers in New Zealand both Se and GSH-Px activities were high.
\end{abstract}

A low nutritional status for selenium in New Zealand residents is illustrated by low urinary excretion and blood concentrations (Thomson, 1972; Griffiths, I973; Griffiths \& Thomson, 1974; Watkinson, 1974). It has now been demonstrated that Se forms an integral part of the enzyme glutathione peroxidase ( $E C$ I.II.I.9) (GSH-Px) (Rotruck, Pope, Ganther, Swanson, Hafeman \& Hoekstra, 1973; Flohé, Gunzler \& Schock, 1973) and that there is a high level of correlation between dietary intake of Se and GSH-Px activities in the blood of chicks and rats (Noguchi, Cantor \& Scott, I973; Hafeman, Sunde \& Hoekstra, 1974; Chow \& Tappel, 1974; Pederson, Whanger \& Weswig, 1975). Thompson (1976) has recently reported a high level of correlation between blood Se levels and GSH-Px activity in sheep, cows and pigs. The aim of this work was to determine whether this relationship also existed for man and whether the low blood Se concentrations in New Zealand are reflected in low GSH-Px activities.

\section{METHODS}

Blood samples were taken from 264 New Zealand residents; normal subjects and patients with a variety of conditions, whose ages ranged from 2 to 92 years. One hundred and eighty of these were normal subjects resident in Auckland, an area not considered to be low in Se: no information was available for these subjects about possible previous residency in other countries or visits overseas. Blood samples were also taken from nine New Zealand residents returned from overseas visits of 7 months to 3 years and seven new settlers resident in this country for less than I month.

Selenium was measured by a modification of the fluorimetric method of Watkinson (1966).

Haemolysates of blood samples for enzyme assay were prepared by adding to an appropriate dilution of whole blood in physiological saline $(9 \mathrm{~g} \mathrm{NaCl} / 1)$, an equal volume of double-strength Drabkin's reagent $\left(0.016 \mathrm{M}-\mathrm{KCN}, 0.0012 \mathrm{M}-\mathrm{K}_{3} \mathrm{Fe}(\mathrm{CN})_{6}\right.$, $0.238 \mathrm{M}-\mathrm{NaHCO}_{3}$ ) and four volumes of $0.02 \mathrm{M}$-phosphate buffer $\left(\mathrm{pH}_{7} \cdot 0\right.$ ) containing 


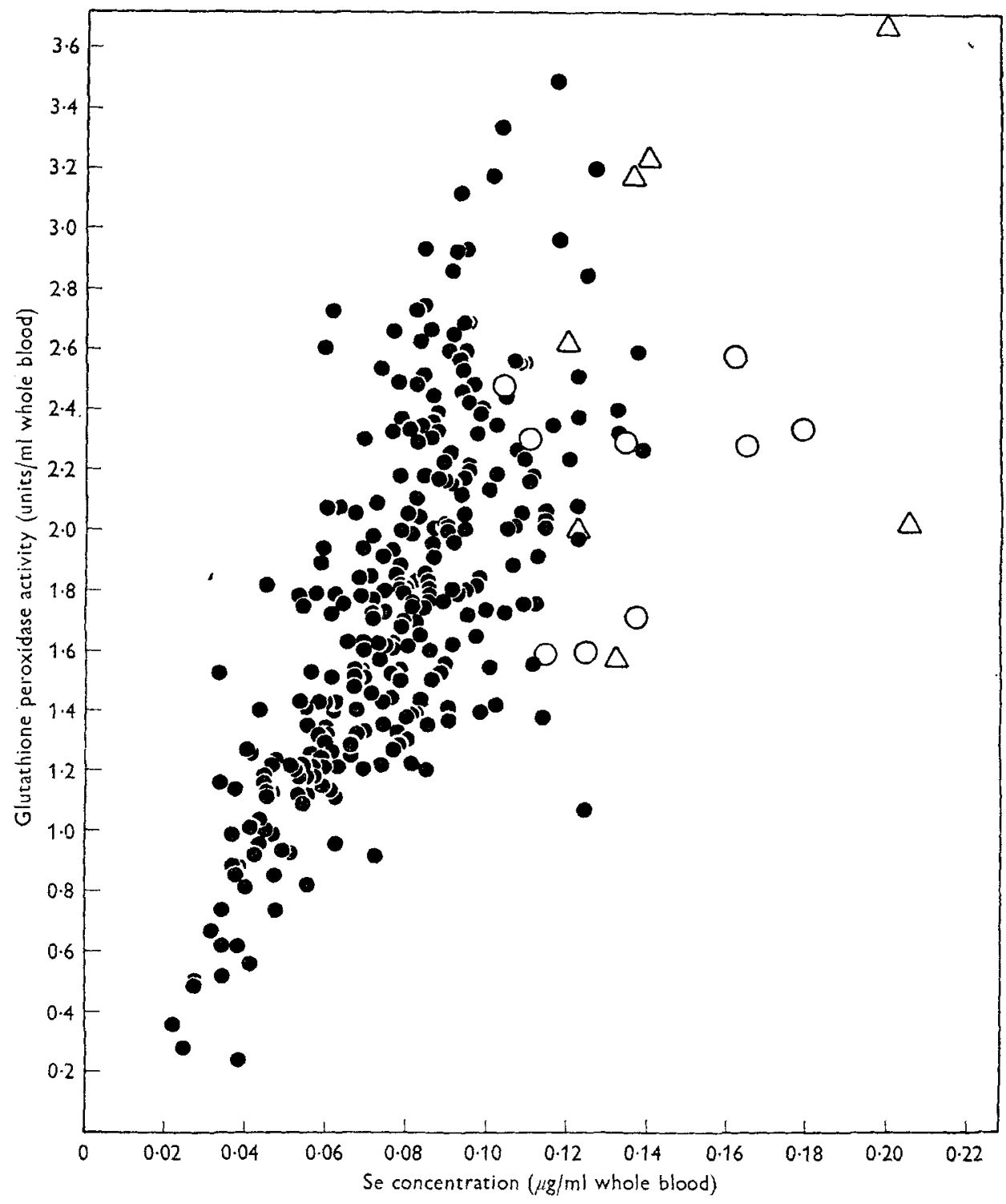

Fig. $x$. Selenium concentrations and glutathione peroxidase $(E C, 1, I x, I, 9)$ activities expressed in units $/ \mathrm{ml}$ whole blood of 264 New Zealand residents (e), nine New Zealand residents returned from overseas visits $(O)$ and seven new settlers to New Zealand $(\triangle)$. For details of experimental procedure see p. 457 .

$0.5 \%(\mathrm{v} / \mathrm{v})$ Triton X-I00. GSH-Px activities were determined by the coupled enzyme procedure with glutathione reductase ( $E C$ I.6.4.2) (GSSG-R) (Paglia \& Valentine, 1967). Assays were carried out in triplicate. Each incubation mixture contained $2 \mu \mathrm{mol}$ glutathione (GSH), 0.5 units GSSG-R (Sigma Chemical Co., St Louis, Missouri, USA), I $\mu \mathrm{mol} \mathrm{NaN}_{3}$, O.I $\mu \mathrm{mol} \mathrm{NADPH}$ in $20 \mathrm{mM}$-phosphate buffer $(\mathrm{pH} 7.0)$ containing $6 \mathrm{~mm}-\mathrm{EDTA}$, in a volume of $0.9 \mathrm{ml}$. The $\mathrm{pH}$ was adjusted to $7 \cdot 0,0.1 \mathrm{ml}$ haemolysate was added and the mixture was incubated for $10-15 \mathrm{~min}$ 
at $25^{\circ}$. The reaction was started by adding $10 \mu \mathrm{l} 30 \mathrm{mM}-t$-butyl hydroperoxide. The reduction of NADPH was followed for $4 \mathrm{~min}$ at $340 \mathrm{~nm}$ using a Gilford Model 222 Spectrophotometer Update System (Gilford Instrument, Oberlin, Ohio, USA) attached to a Beckmann DU Spectrophotometer (Beckmann Instruments Inc., Fullerton, California, USA). Enzyme activities were calculated between 2 and $4 \mathrm{~min}$ and a small non-enzymic rate of NADPH oxidation was subtracted from the overall rate. One enzyme unit of activity was defined as I $\mu \mathrm{mol}$ NADPH oxidized $/ \mathrm{min}$. Results were expressed as units/ml whole blood and units/g haemoglobin $(\mathrm{Hb})$.

A stock sample of blood was assayed with each series and enzyme activity proved to be stable at $4^{\circ}$ for as long as 6 weeks. Twenty-four assays on different days gave a mean activity of $\mathrm{I} \cdot \mathrm{I} 9(\mathrm{SD} 0.06)$ units $/ \mathrm{ml}$ whole blood and 9.52 (SD 0.48 ) units $/ \mathrm{g} \mathrm{Hb}$.

\section{RESULTS AND DISCUSSION}

The relationship between Se concentrations and GSH-Px activities in whole blood expressed in units GSH-Px/ml whole blood is illustrated in Fig. I. The results show a highly significant correlation between Se concentration and GSH-Px activities in whole blood of 264 New Zealand residents $(r 0.71, P<0.001)$. The correlation between Se concentration and GSH-Px (units/g Hb) was also highly significant ( $r 0.68, P<0.001)$. Whole blood was used in this study because it was not possible to separate into erythrocytes and plasma the blood samples obtained from the I 83 Auckland subjects. Since $90-95 \%$ of the total GSH-Px activity but only $60 \%$ of total Se is present in the erythrocytes (unpublished results), it might have been preferable to investigate the relationship between GSH-Px activity and erythrocyte Se.

The results suggested a higher correlation between Se and GSH-Px (units/ml whole blood) for one half of the 264 subjects whose Se concentrations were below $0.08 \mu \mathrm{g} / \mathrm{ml}(r 0.72, P<0.00 \mathrm{r})$ than for those above this concentration $(r 0.27$, $P<0.01$ ). For an arbitrarily chosen Se concentration of $0.10 \mu \mathrm{g} / \mathrm{ml}$, a little above the mean for New Zealand, the correlation coefficient for concentrations below this value was slightly greater $(r 0.74, P<0.001$ for 222 subjects) than for the total group of subjects, while above this value there was no significant relationship $\left(r 0_{1} 17\right.$ for 42 subjects). On the other hand there was no significant correlation for New Zealanders returning from overseas visits for the few subjects available; GSH-Px activities were not noticeably increased above those of New Zealand residents, although Se concentrations were often considerably greater. But for five out of seven new settlers to New Zealand both Se concentrations and GSH-Px activities were higher.

These observations suggest a number of possibilities. (I) Above a Se concentration of about $0.10 \mu \mathrm{g} \mathrm{Se} / \mathrm{ml}$, GSH-Px activity is not noticeably increased, suggesting either that this Se concentration is optimal and that a Se intake that maintains this concentration is adequate for function as measured by GSH-Px activities, or, that above this concentration other factors might play a greater role in influencing GSH-Px levels. (2) The observation that New Zealanders who had recently returned from 
an overseas visit of up to 3 years did not have higher GSH-Px levels corresponding to their higher Se concentrations whereas some new settlers did, could suggest that a longer period of time on an increased Se intake might be needed for higher blood Se to be reflected in GSH-Px activities. (3) It is also possible that New Zealanders have become adapted to a reduced intake of Se, but if not, the lower blood Se might result in some kind of impaired function or deficiency.

These possibilities have been based upon the results from only a small number of new settlers and New Zealanders returning from an overseas visit and are being investigated further. However, the results show that there are some New Zealand residents with very low blood Se and low GSH-Px activities who might be at risk. It also appears that, at least for New Zealand residents and particularly for those with low blood Se, the assay of GSH-Px activities in whole blood might be another suitable method for assessing the nutritional status of $S e$ as suggested by a number of workers (Hafeman et al. 1974; Burk, 1976; Ganther, 1976).

We are particularly grateful to the subjects for their willing co-operation; to $\mathrm{Dr} R$. J. Swannell, Auckland Adventist Hospital, Dr O. Chapman, Parkside Hospital, Dr A. van Rij, Department of Surgery and Miss Robyn McKenzie for their assistance in collecting the blood samples, to Professor R. D. H. Stewart, Department of Medicine for his valuable advice, and to Miss Gaylene Friend and Mr L. M. Cantwell for their technical assistance. This study was supported by the Medical Research Council of New Zealand and the New Zealand Medical Research Distribution Committee.

\section{REFERENCES}

Burk, R. F. (1976). In Trace Elements in Human Health and Disease, vol. II [A. S. Prasad, editor]. London \& New York: Academic Press.

Chow, C. K. \& Tappel, A. L. (r974). F. Nutr. ro4, 444.

Flohé, L., Gunzler, W. A. \& Schock, H. H. (1973). Febs Letters 32, 132.

Ganther, H. E. (1976). In Trace Elements in Human Health and Disease, vol. II [A. S. Prasad, editor]. London \& New York: Academic Press.

Griffiths, N. M. (1973). Proc. Univ. Otago med. Sch. 5r, 8.

Griffiths, N. M. \& Thomson, C. D. (1974). N.Z. med. F. 80, 199.

Hafeman, D. G., Sunde, R. A. \& Hoekstra, W. G. (1974). F. Nutr. ro4, 580.

Noguchi, T., Cantor, A. H. \& Scott, M. L. (1973). Y. Nutr. 103, 1502.

Paglia, D. E. \& Valentine, W. N. (1967). F. Lab. clin. Med. 70, 158.

Pederson, N. D., Whanger, P. D. \& Weswig, P. H. (1975). Nutr. Rep. Int. x1, 429.

Rotruck, J. T., Pope, A. L., Ganther, H. E., Swanson, A. B., Hafeman, D. G. \& Hoekstra, W. G. (1973). Science r79, 588.

Thompson, R. H, (1976). Res, vet. Sci. 20, 229.

Thomson, C. D. (1972). Proc. Univ. Otago med. Sch. 50, 3 r.

Watkinson, J. H. (1966). Analyt. Chem. 32, $98 \mathrm{I}$.

Watkinson, J. H. (1974). N.Z. med. Y. 80, 202. 